\title{
Determination of Chlorpyrifos (Diethyl-3,5,6-trichloropyridyl phosphorothioate) in Cured Tobacco*
}

by Mary J. Toet and L. Toet

Tobacco-Research Board of Rhodesia, Salisbury, Rhodesia

\section{INTRODUCTION}

A method for the determination of chlorpyrifos (diethyl3,5,6-trichloropyridyl phosphorothioate) residues in cured tobacco is presented. Chlorpyrifos is now recommended by the Tobacco Research Board of Rhodesia as a soil insecticide for the control of cutworm. Its use on tobacco necessitated a study of residual chlorpyrifos in cured leaf and the tobacco offered for sale will be monitored using this method.

The method described affords a determination of chlorpyrifos which is free from interference from all organophosphate compounds recommended and allowed in Rhodesia on tobacco, such as monocrotophos, methomyl, disulfoton, demeton-S-methyl, dimethoate and menazon.

\section{METHOD}

\section{I Apparatus.}

2.1.I Extractor Soxhlet "Quickfit" borosilicate glass.

2.1.2 Extraction thimbles pyrex with a sintered glass disc, porosity I.

2.1.3 Cleanup column I (Figure 1).

2.1.4 Rotary evaporator Heidolph complete with temperature regulated water bath and mercury vacuum indicator.

2.1.5.1 Gas-liguid dhromatograph - electron capture, (Philips Pye Unicam Model R, fitted with a nickel ${ }^{63}$, Io millicuries electron capture detector).

Chromatograph:

Philips Model R.

Detector:

Electron capture, $\mathrm{Ni}^{68}, 10$ millicuries.

Column:

$1.0 \mathrm{~m}$ glass, $4 \mathrm{~mm}$ inside diameter.

Liquid phase:

$\mathrm{OV}-17+\mathrm{QF}-1$ at $11 \%$.

Support:

Gas-Chrom Q, 80-100 mesh.

Column temperature: $205^{\circ} \mathrm{C}$.

Detector temperature: $\quad 240^{\circ} \mathrm{C}$.

- T.R.B. Research Paper No. 148.

Received for publication: 30th July, 1975.
Injection port

temperature:

Carrier gas:

Chart speed:

Sample size:

Retention time of chlorpyrifos:

If desired a $2.0 \mathrm{~m}$ column can be used, with a carrier gas flow of $60 \mathrm{ml} / \mathrm{min}$. Under these conditions the retention time of chlorpyrifos is 4 minutes -45 seconds.

Figure 1. Glase column used for the cleanup of chlorpyrifos.

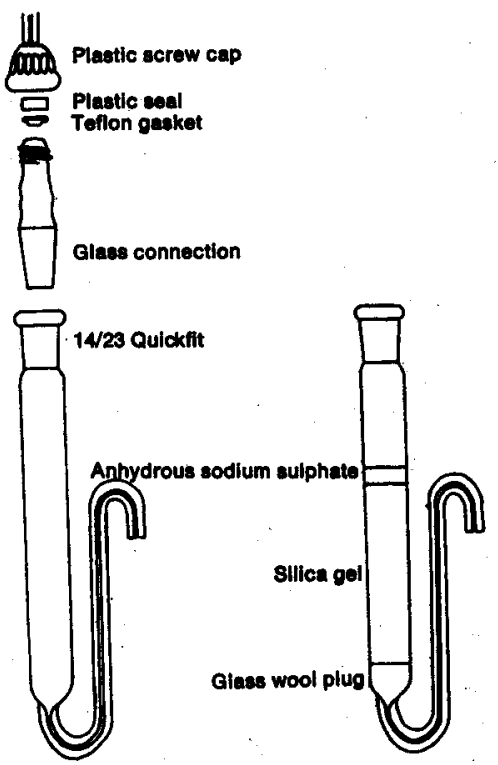


2.1.5.2 Gas-liquid dromatograph, thermionic detector (Philips Pye Unicam Model 104 fitted with a caesium bromide tipped thermionic detector).

Chromatograph:

Detector :

Column:

Liquid phase:

Support:

Column temperature:

Gas:

Gas:

Carrier gas :

Chart speed:

Sample size:

2.1.5.3 Philips flat bed recorders P.M. 8000 .

\subsection{Chemicals and Reagents}

2.2.1 A.R, petroleum ether, boiling range $40^{\circ}-60^{\circ} \mathrm{C}$, distilled over sodium hydroxide before use.

\subsubsection{A.R. acetone distilled before use.}

\subsubsection{Anaesthetic ether.}

2.2.4 Florisil prepared as in the Coresta* reference method for the determination of organochlorine pesticide residues on tobacco (2).

2.2.5 Silica gel after Ramsey and Patterson (I), 80 to 100 mesh.

2,2.6 Chlorpyrifos standards prepared by dissolving $0.1000 \mathrm{~g}$ A.R. chlorpyrifos standard in $10 \mathrm{ml} \mathrm{A.R.} \mathrm{ace-}$ tone and making up to $100 \mathrm{ml}$ with distilled petroleum ether. This is the $1 \times 10^{-8} \mathrm{~g} / \mathrm{ml}$ standard from which standards to $1 \times 10^{-7} \mathrm{~g} / \mathrm{ml}$ are derived by dilutions. The $x \times 10^{-5} \mathrm{~g} / \mathrm{ml}$ standard was diluted to give 0.1 to $0.5 \mathrm{ng} / 5 \mathrm{\mu l}$ for linearity testing.

\subsection{Procedure}

2.3.1 Milling of Tobacco: Using a Wiley Mill grind 2-3 hands of tobacco (circa 500 grams) all to pass through a $1 \mathrm{~mm}$ mesh sieve.

2.3.2 Drying of Milled Tobacco: By means of a sample splitter reduce the milled sample to about $100 \mathrm{~g}$. Analyse the sample as received and correct for moisture; do not transfer the sample to a forced draught oven at $45^{\circ} \mathrm{C}$ and leave overnight. Spiked samples treated in this manner lost dorpyrifos.

* Cooperation Centre for Scientific Research Relative to Tobacco, Paria.
2.3.3 Preparation for Extraction: To a clean, dry, sintered glass extraction thimble (see 2.1.2) add $5 \mathrm{~g}$ of Florisil and tap gently to obtain a homogeneous layer. Weigh $5 \mathrm{~g}$ of the tobacco and $10 \mathrm{~g}$ of Florisil (see 2.2.4) onto a filter paper and mix thoroughly. Carefully add this to the Florisil layer and tap. When settled, place a wad of oil-free cotton wool on the top of the mixture.

2.3.4 Extraction: Insert the glass thimble in the Soxhlet and extract with A.R. distilled acetone for 8 hours.

2.3.5 Concentration: Remove the $250 \mathrm{mI}$ flat-bottom extraction flask from the Soxhlet and transfer the contents to a round-bottom flask for use on the Heidolph Rotary Evaporator. Evaporate at a vacuum of $40 \mathrm{~mm} \mathrm{Hg}$. Ice cold water must be used to cool the condenser. Evaporate the sample to remove all free acetone, i.e. to near dryness, redissolve the sample in $2 \mathrm{ml}$ of petroleum ether. The extract is then ready for column chromatography.

2.3.6 Column Chromatography: Prepare the chromatography column with a glass wool plug at the base. Add petroleum ether to half fill the column, weigh $7.5 \mathrm{~g}$ silica gel, and transfer some of the silica gel [after Ramsay and Patterson, selected and stored as described by Toet \& Toet (x)] to it. Stir the petroleum ether and silica gel through a small funnel into the glass column to obtain a uniform slurry. Slowly add the entire $(7.5 \mathrm{~g})$ silica gel, ensuring that the slurry is kept homogeneous by additions of petroleum ether and continuous stirring. Allow the column to settle and add $2 \mathrm{~g}$ anhydrous sodium sulphate. Fit the elution funnel to the glass dromatography column by means of the connector (as shown in Figure 1 ). Pass a further $50 \mathrm{ml}$ of petroleum ether through the column, discard eluate. Introduce the sample to the top of the column and elute with $150 \mathrm{ml}$ petroleum ether. Collect the petroleum ether eluate and adjust to $100 \mathrm{ml}$. Elute with $150 \mathrm{ml} 5 \%$ ether in petroleum ether. Collect the $5 \%$ ether eluate and evaporate to $5 \mathrm{ml}$ on the Heidolph Rotary Evaporator; make up to $100 \mathrm{ml}$ with petroleum ether. Both eluates must be screened for chlorpyrifos, because, depending on the nature of the tobacco, variable quantities of dilorpyrifos can be found in both eluates.

2.3.7 Gas-Liquid Chromatography: Most analyses can be done with the electron capture detector (2.1.5.x). Chlorpyrifos elutes from the liquid phase between aldrin and o,p'-DDE. There are no other chlorinated pesticides with the same retention time. Toxaphene can be readily separated on a $2 \mathrm{~m}$ column for the electron capture detector and on the $1.09 \mathrm{~m}$ column the thermionic detector gave good separation. Chlorpyrifos standards did not show linearity at concentrations greater than $0.3 \mathrm{ng} / 5 \mu \mathrm{l}$ (Figure 2), therefore a suitable standard was $0.25 \mathrm{ng} / 5 \mu \mathrm{l}$. The column requires constant conditioning; after every three samples it is advisable to test the standards, particularly while running the $5 \%$ ether eluates. Under the specified conditions $99 \%$ of the chlorpyrifos is found in the $5 \%$ ether eluate. Figure 3, where peak height is plotted against con- 
Figure 2. Callbration curve of chlorpyrifos for the electron capture $\mathrm{Ni}^{\text {(3) }}$ detector.

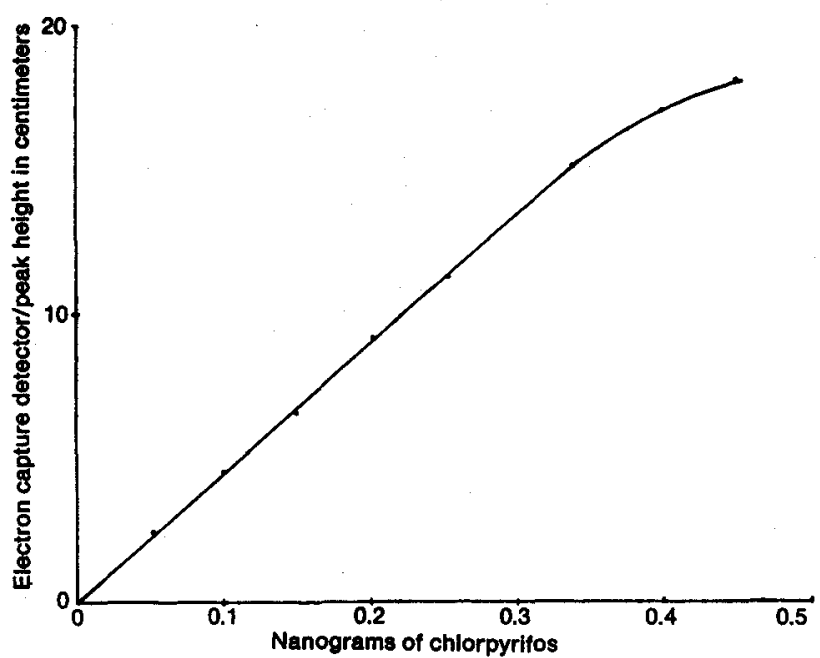

Figure 3. Callbration curve of chlorpyrifos for the thermlonic detector fitted with caeslum bromide tip (A.F.I.D.).

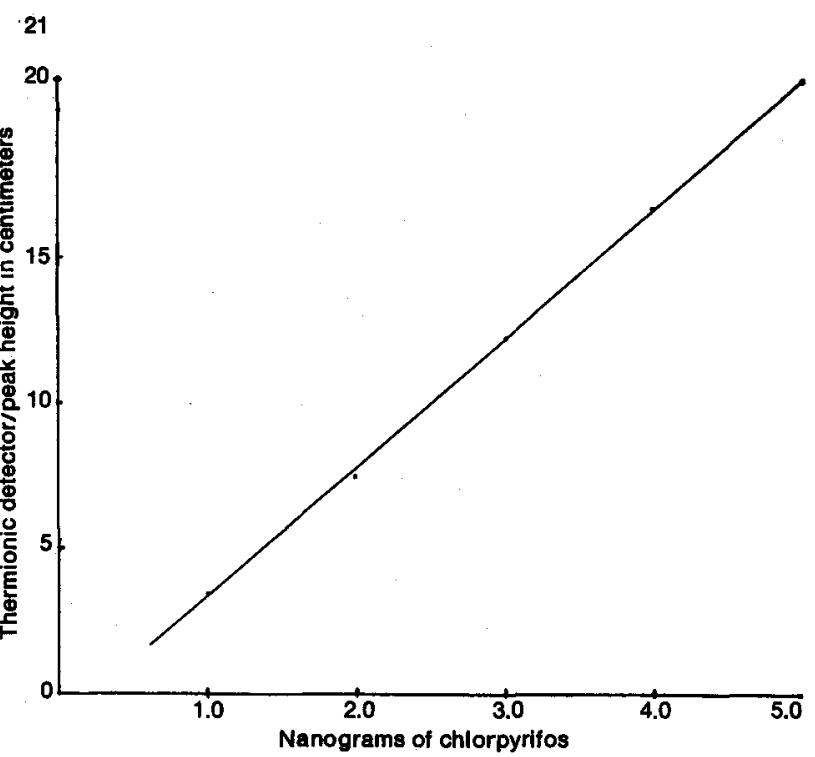

centration for the thermionic detector, shows chlorpyrifos linear in the range $1-5 \mu \mathrm{g}$. Samples must be concentrated ten times for injection into the thermionic detector gas-liquid chromatograph.

\section{RESULTS AND DISCUSSION}

The advantage of using the thermionic detector is that there are no interfering peaks from tobacco co-extractives, whereas the electron capture detector becomes contaminated by the $5 \%$ ether eluate even though most of the ether has been removed by evaporation prior to making up to $100 \mathrm{ml}$ with petroleum ether. This method gave reproducible results and recoveries from spiked samples were excellent. The lower limit of detection under the above conditions was $0.05 \mu \mathrm{g} / \mathrm{g}$. Figure 4.1 shows the electron capture, and Figure 4.2 the thermionic gas-liquid chromatograms of a standard and a spiked sample.
Table 1. Recovery of chlorpyrifos added to $10 \mathrm{~g}$ tobacco, measured by electron capture and thermionic detectors.

\begin{tabular}{c|c|c|c}
\hline \multirow{2}{*}{ Sample } & \multirow{2}{*}{$\begin{array}{c}\text { Level of } \\
\text { spiking } \\
(\mu \mathrm{g} / \mathrm{g})\end{array}$} & $\begin{array}{c}\text { \%lectron } \\
\text { capture } \\
\text { detection } \\
(2 \mathrm{~m} \text { column })\end{array}$ & $\begin{array}{c}\text { Thermionic } \\
\text { detection } \\
\text { (1.09 m column })\end{array}$ \\
\cline { 3 - 4 } & & 108 & 102 \\
2 & 0.2 & 100 & 99 \\
3 & 0.4 & 97 & 96 \\
4 & 0.6 & 97 & 100 \\
5 & 0.8 & 95 & 98 \\
\hline
\end{tabular}

Recoveries of spiked tobacco samples are given in Table I for both the electron capture detector and the thermionic detector. The samples were first measured by the electron capture detector and then after ten times concentration measured by the thermionic detector.

\section{SUMMARY}

A method for determining chlorpyrifos in cured tobacco by gas-liquid chromatography, using electron capture and thermionic detection, is described.

Ground, cured tobacco, mixed with Florisil, is Soxhlet extracted with acetone for eight hours. The extract is evaporated to dryness, redissolved in a small amount of petroleum ether, and eluted through a silica gel column using first petroleum ether and then $5 \%$ ether in petroleum ether. The volumes of the eluates are adjusted and their chlorpyrifos content determined by gas-liquid chromatography, using an electron capture detector and, for confirmation, a thermionic detector. Recoveries from spiked samples are good, and results are reproducible.

\section{ZUSAMMENFASSUNG}

Es wird eine Methode beschrieben, mit deren Hilfe Chlorpyrifos in getrocknetem Tabak durch Gaschroma, tographie unter Einsatz eines Elektroneneinfang- und eines thermionischen Detektors bestimmt werden kann.

Gemahlener getrockneter Tabak wird mit Florisil gemischt und acht Stunden lang mit Aceton in einem Soxhlet extrahiert. Der Extrakt wird bis zur Trockne eingedampft, in einer kleinen Menge Petroläther wieder gelöst und über eine Kieselgelsäule unter Benutzung von zunächst Petroläther und dann $5 \%$ Äther in Petroläther eluiert. Die Eluatmengen werden normiert, und ihr Gehalt an Chlorpyrifos wird durch Gaschromatographie unter Verwendung eines Elektroneneinfangdetektors und eines thermionischen Detektors (zur Kontrolle) bestimmt. Die Wiederauffindung bei dotierten Proben ist gut. Die Ergebnisse sind reproduzierbar. 
Figure 4.1. Eloctron capture detector gas chromatograms of A: chlorpyriloe standard (0.125 $\mathrm{ng})$, B: $5 \mathrm{~g}$ tobacco splked with $0.125 \mathrm{ng} / 2.5 \mu \mathrm{l}$ of the $100 \mathrm{ml}$ potroleum other eluate, and C: $5 \mathrm{~g}$ tobacco splked whth $0.125 \mathrm{ng} / 2.5 \mu \mathrm{l}$ of the $100 \mathrm{mi} 5 \%$ ether in petroleum ether eluate.

(Note for convenience, a 2 m column was used for electron capture detection, and the attenuation was selected to give the largest deflection for recovery tests on spiked samples.)

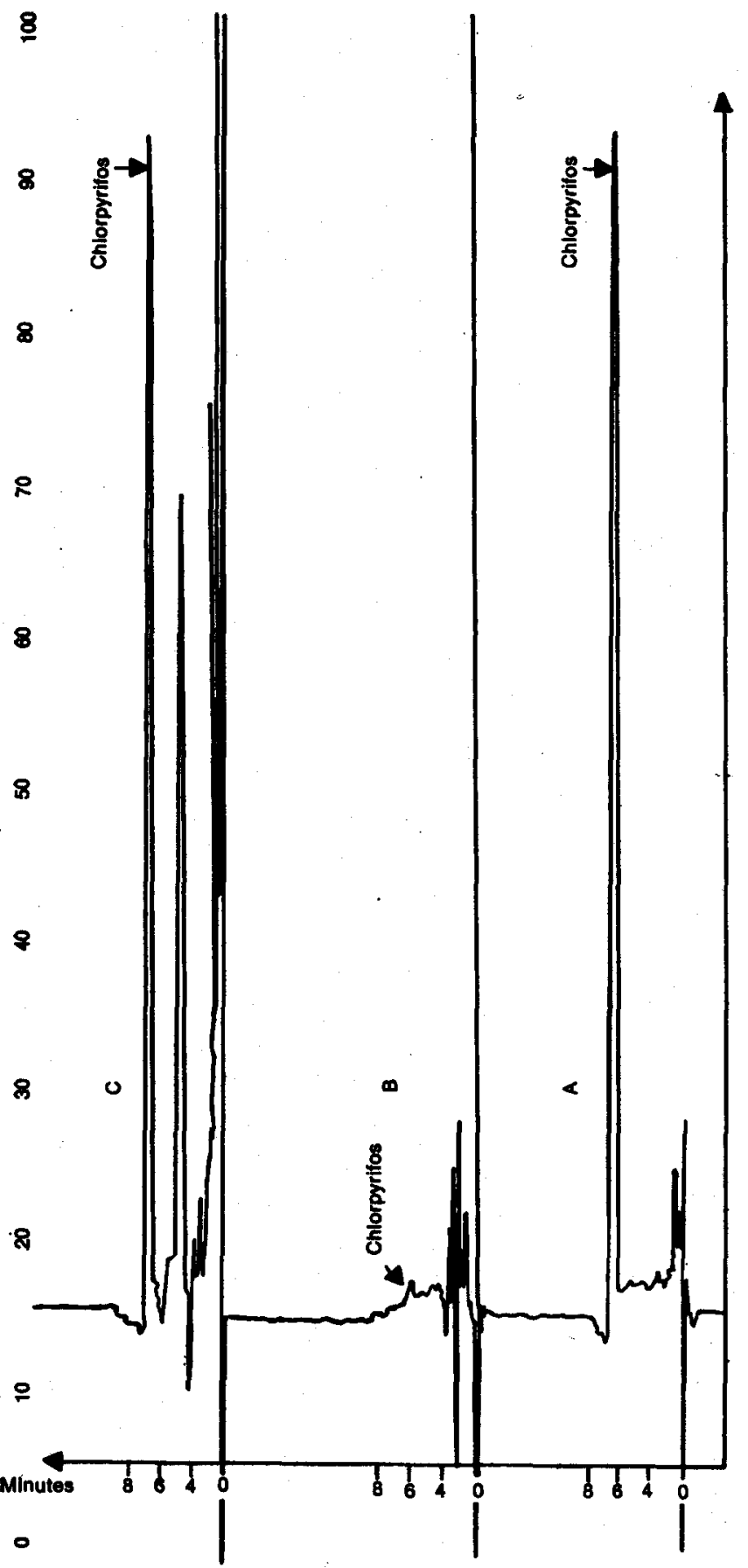

\section{RESUME}

On décrit une méthode par laquelle on peut déterminer le "chlorpyrifos" dans le tabac séché par chromatographie gaz-liquide, en utilisant la capture d'électrons et la détection thermionique.

On sournet le tabac séché et moulu, auquel on mélange du Florisil, à une extraction à l'acétone Soxhlet durant
Figure 4.2. Thermionic delector gas chromatograms of D: chlorpyrtios standard (1.25 $\mathrm{ng})$, and E: $5 \mathrm{~g}$ tobacco splked with $1.25 \mathrm{ng} / 2.5 \mu \mathrm{l}$ of the $100 \mathrm{ml} 5 \%$ other in potroleum ether.

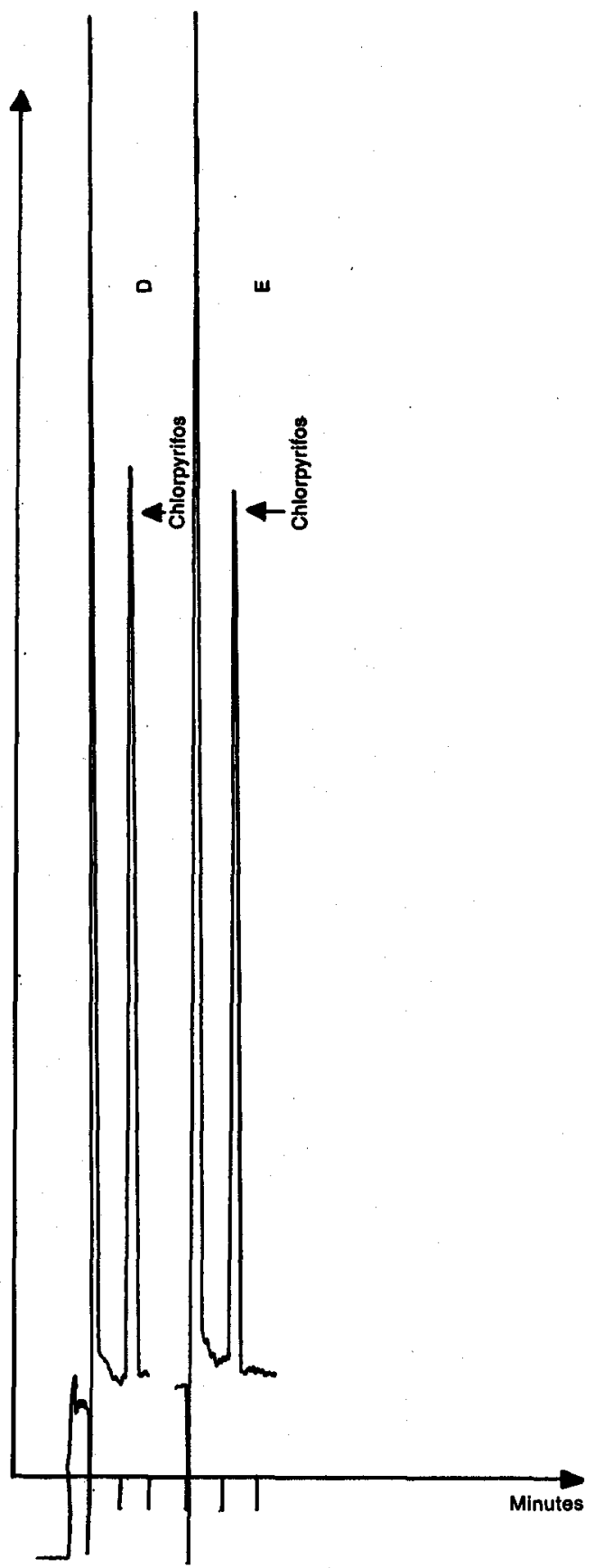

huit heures. On évapore l'extrait à sec, le redissout dans une petite quantité d'éther de pétrole, ensuite on l'élue sur colonne de silica-gel, utilisant d'abord de l'éther de pétrole et ensuite une solution d'éther à $5 \%$ dans de l'éther de pétrole. On ajuste le volume des éluats et on détermine leur teneur en «chlorpyrifos» par chromatographie gaz-liquide, utilisant pour ceci un détecteur à capture d'électrons, et on confirme avec un 
détécteur thermionique. La récupération des quantités ajoutées aux échantillons est bonne, et les résultats sont reproductibles.

\section{REFERENCES}

1. Toet, L., and Mary J. Toet: Method for one step DDT extraction and cleanup in tobacco for monitoring purposes; Beitr. Tabakforsch. 7 (1973) 93.

2. Coresta Recommended Method No. 2: Determination of organochlorine pesticide residues in to- bacco; Coresta Information Bulletin 1974-2, p. 27, and Beitr. Tabakforsh. 8 (1975) 109.

\section{Adknowledgements}

Miss L. E. Williams for technical assistance, Miss S. Sperring for assistance with diagrams.

The authors' address:

Tobacco Research Board of Rhodesia, P.O. Box 19og, Salisbury, Rhodesia. 